\title{
CONTENTS
}

\author{
Illustrations ix
}

Foreword $x i$

1. THE UNITED STATES AND THE REPUBLIC OF KOREA: THE PAST 1

Evolution of the US-ROK Relationship 5

Korean Foreign Policy 11

Korea in US Strategic Policy 12

\section{THE MILITARY BALANCE OF POWER IN} NORTHEAST ASIA 15

The Nature of the Confrontation 16

Asia-The Larger Context 21

North-South Relations on the Korean

Peninsula 26

Sino-US Relations 29

The Importance of the Sino-Soviet Conflict 30

The Role of US and Soviet Forces 33

Current US and Soviet Capabilities 36

A Look Ahead 38

\section{SOUTH KOREA'S ECONOMY 41}

US-ROK Economic Considerations 47

South Korean Economic Development 48 